\title{
Problems of the Non-Cash Payments Development in the Russian Federation on the Example of the North Caucasus
}

\author{
Nadezhda Necheukhina $^{1}$, Victoria Kremleva $^{1,2}$, and Olga Dudina ${ }^{1}$ \\ ${ }^{1}$ Ural State University of Economics, 620144 Ekaterinburg, Russia \\ ${ }^{2}$ Dagestan State University of National Economy, 637008 Russia
}

\begin{abstract}
Currently, the use of cash payments in the economy is an undesirable element since it is the basis for the shadow economy development. The willingness of the Russian Federation Government to switch to non-cash payments has reason. The implementation of many state programs depends on the non-cash payments development, especially in developing regions. Non-cash payments allow to take control of the movement of funds, as well as assess its origin. Moreover, they contribute to the growth of tax revenues to the budget. The purpose of the article is to analyze the payment system development of the Russian Federation, the development level of non-cash payments in the territory of the Russian Federation in the context of the regions, to identify the main reasons that impede the payment infrastructure development. Much attention is paid to the regions, since it is here that the entering of banking services leaves much to be desired. The goals set by the authors - to carry out a comparative analysis, horizontal and vertical analysis, to identify the main indicators of the level of «non-cash» settlements. Accordingly, build hypotheses and draw conclusions and recommendations. It is necessary to transfer as many transactions as possible to non-cash payments, and this depends on the interest of consumers in settlements with bank cards and other non-cash instruments.
\end{abstract}

\section{Introduction}

For the first time in history, in the 4th quarter of 2019, the share of non-cash expenses in Russia crossed the 50\% mark. In 2019, individuals actively used bank cards in retail chains, more than half of all household expenses were made with cards. Even 10 years ago, expenses in trade and service networks (TSN) accounted for only $10 \%$ of the total population expenses, and the number of cards was almost three times less than now.

The purpose of the article is to study the payment system development of the Russian Federation, the development level of non-cash payments in the territory of the Russian Federation in the context of the regions, to identify the main reasons that impede the payment infrastructure development. The resulting tasks are to analyze, using comparative analysis, horizontal and vertical analysis, as well as statistical tools, the main indicators of the level of «non-cash» settlements. Accordingly, build hypotheses and draw conclusions and recommendations. 


\section{Materials and Methods}

The country's money supply consists of several aggregates: the M0 unit is cash in circulation, the M1 unit is M0 and cash in banks on demand. There is also an M2 unit, which, in addition to M0 and M1, includes urgent funds in banks. The structure of the money supply in the country indicates the level of the non-cash payments development. Table 1 shows the share of cash in the Russian Federation over the past 9 years: since 2011, it has decreased from $25 \%$ to $19 \%$ [6]:

Table 1. Money supply of the Russian Federation for 2011-2019 (billion rubles)

\begin{tabular}{|c|c|c|c|c|c|c|}
\hline \multirow[t]{2}{*}{ Date } & \multirow[b]{2}{*}{$\begin{array}{c}\text { Cash in } \\
\text { circulation } \\
\text { outside the } \\
\text { banking } \\
\text { system } \\
\text { (money } \\
\text { supply M0) }\end{array}$} & \multirow{2}{*}{$\begin{array}{c}\text { Transferabl } \\
\text { e deposits }\end{array}$} & \multicolumn{2}{|c|}{ including: } & \multirow[b]{2}{*}{$\begin{array}{c}\text { Money } \\
\text { supply in } \\
\text { the } \\
\text { national } \\
\text { definitio } \\
\text { n (money } \\
\text { supply } \\
\text { M2) }\end{array}$} & \multirow[b]{2}{*}{$\begin{array}{l}\text { Share of } \\
\text { cash in } \\
\text { the } \\
\text { money } \\
\text { supply }\end{array}$} \\
\hline & & & population & $\begin{array}{c}\text { non-financial } \\
\text { and financial } \\
\text { (except credit) } \\
\text { organizations }\end{array}$ & & \\
\hline 01.01.2011 & 5063 & 5797 & 6411 & 2741 & 20011,9 & $25 \%$ \\
\hline 01.01 .2012 & 5939 & 6818 & 7684 & 3764 & 24204,8 & $25 \%$ \\
\hline 01.01 .2013 & 6430 & 7264 & 9139 & 4331 & 27164,6 & $24 \%$ \\
\hline 01.01 .2014 & 6986 & 8526 & 10838 & 4806 & 31155,6 & $22 \%$ \\
\hline 01.01 .2015 & 7172 & 8170 & 10670 & 5605 & 31615,7 & $23 \%$ \\
\hline 01.01 .2016 & 7239 & 9276 & 12774 & 5890 & 35179,7 & $21 \%$ \\
\hline 01.01.2017 & 7715 & 9928 & 14634 & 6142 & 38418,0 & $20 \%$ \\
\hline 01.01.2018 & 8446 & 11063 & 16077 & 6856 & 42442,2 & $20 \%$ \\
\hline 01.01.2019 & 9339 & 12285 & 17186 & 8300 & 47109,3 & $20 \%$ \\
\hline 01.01.2020 & 9658 & 14203 & 18398 & 9421 & 51680,0 & $19 \%$ \\
\hline
\end{tabular}

Source: Official website of the Bank of Russia: https://cbr.ru/statistics/ms/

And this is still a high share, for example, for comparison, in the UK, the share of cash in circulation is only $3,3 \%$. We can say that in developed countries, cash tends to disappear.

The high rates of money supply depreciation in the country and passing the $50 \%$ milestone do not indicate at all that all regions have also a developed infrastructure of non-cash payments. $50 \%$ is only the average for Russia, but if we take individual regions, the situation there is very different from the average Russian level. The studied set of indicators is heterogeneous and differentiated. Statistically, this differentiation between the subjects of the Russian Federation is shown in Figure 1,2 and Table 2,3. The republics of the North Caucasus, in particular, R. Dagestan, are a prime example of the region's differentiation. We have identified the most informative indicators of the «non-cash» payment: these are trade non-cash turnover per card, the share of non-cash payments in the total turnover, the number of purchases from 1 card per month, the average check amount for non-cash purchases:

Table 2. The main indicators of the non-cash payments development in the Russian Federation, the North Caucasus Federal District and the Republic of Dagestan in 2019 [7]

\begin{tabular}{|l|l|l|l|}
\hline Indicator & Russia & NCFD & R. Dagestan \\
\hline $\begin{array}{l}\text { Trade non-cash turnover on cards for 1 card, rub. per } \\
\text { month }\end{array}$ & 8194 & 4490 & 3234 \\
\hline $\begin{array}{l}\text { The share of non-cash payments in retail chains of the total } \\
\text { number of transactions with payment cards, \% (as of } \\
1.07 .2019 \text { ) }\end{array}$ & 49 & 31 & 21 \\
\hline Number of purchases from 1 card per month & 10 & 6 & 5 \\
\hline Average check amount for purchases in retail chains, RUB & 857 & 728 & 721 \\
\hline Provision with terminals per 1000 inhabitants & 21 & 6,33 & 1,7 \\
\hline
\end{tabular}


The share of non-cash purchases in the NCFD is $31 \%$, which is much higher than, for example, in the R. Dagestan (21\%) and the Chechen Republic (13\%), Stavropol Territory (40\%), Russia (49\%) (Table 2).

An important indicator of the non-cash payments development is the average purchase check. In Dagestan, the average check in 2019 is 721 rubles, in Russia as a whole - 857. Here, a low check amount is due not to a large number of terminals and everyday small purchases, but to a low level of consumer demand, or rather, a low level of income. In its calculations, the Bank of Russia pays attention to the dynamics of this particular indicator. For example, it was revealed that the threshold amount, starting from which citizens tend to use card payments in 2018, decreased over the year from 1545 to 1230 rubles [8]. This is evidenced by the data on the number of cards purchases per month: in Russia, the number of card payments per month is 10 (120 per year), in Dagestan 5 (60 per year), in Chechnya 2 (24 per year).

For 9 months of 2019, the trade turnover in RD amounted to 451120,5 million rubles, and the turnover in retail chains by bank cards for this period was 43814 which is $9,7 \%$. In the same period of the previous year, this index was $8 \%$ [7].

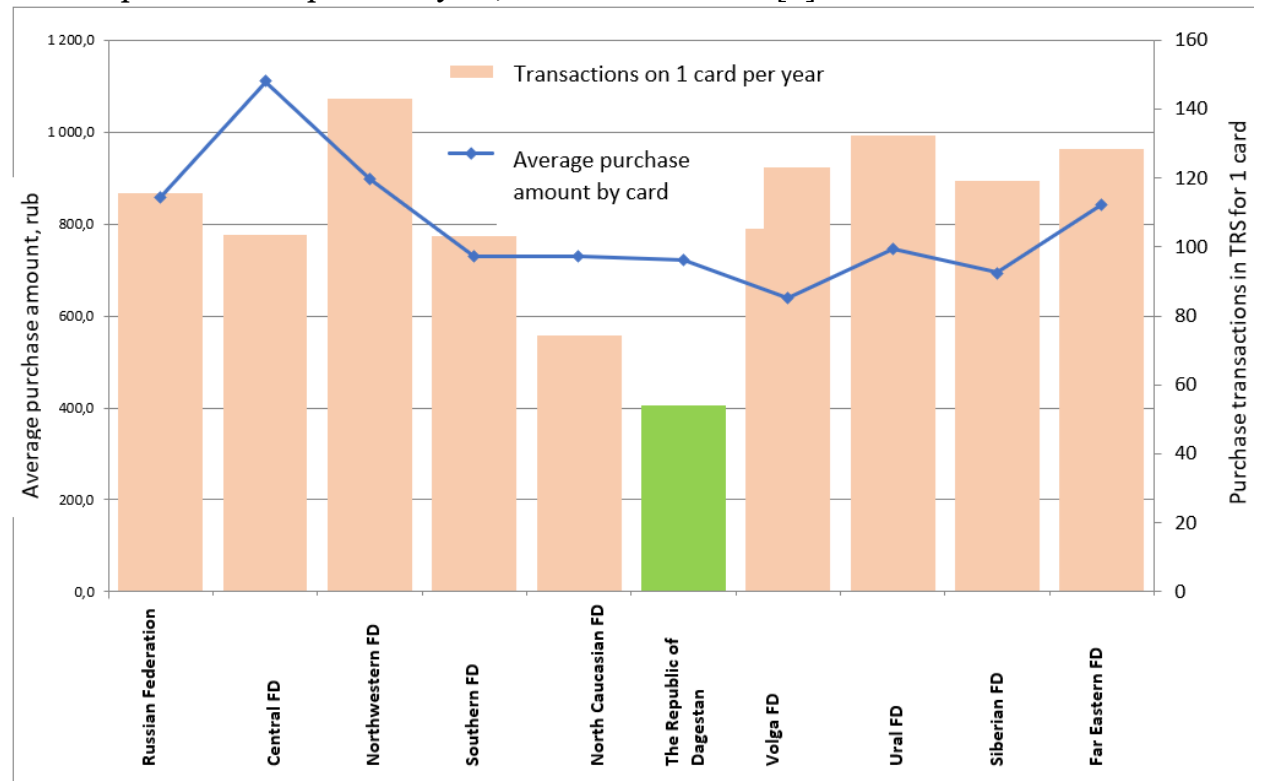

Fig. 1. Main indicators of operations with bank cards by federal districts of the Russian Federation for 2019

In the republics of the North Caucasus the population supply ratio with payment infrastructure continues to grow every year, and as at July 1, 2019 there were 21 thousand payment card receiving devices per 1 million residents in Russia, this figure is only 1,7 thousand in Dagestan (table 2). There are on average 6,33 thousand terminals per 1000 residents in the NCFD. A relatively high number of terminals are located in the Stavropol Territory: 14 thousand units per 1000 residents, but even this is below the average Russian level. 
Table 3. Statistics of the main indicators sample of the non-cash payments development in the context of the Russian Federation entities

\begin{tabular}{|l|r|r|r|}
\hline Descriptive statistics indicator & $\begin{array}{r}\text { The number of } \\
\text { purchases in the TSN } \\
\text { for 1 card in 2019 }\end{array}$ & $\begin{array}{r}\text { Turnover in TSN } \\
\text { on 1 card per } \\
\text { month, rub. }\end{array}$ & $\begin{array}{r}\text { Share of turnover } \\
\text { in TSN in total } \\
\text { turnover in 2019, } \\
\text { \% }\end{array}$ \\
\hline Average & $\mathbf{1 1 7 , 9}$ & $\mathbf{7 0 7 5 , 9}$ & $\mathbf{4 4 , 9}$ \\
\hline Standard error & 3,4 & 296,5 & 1,0 \\
\hline Median & 120,2 & 6529,2 & 46,2 \\
\hline Mode & 123,0 & 7444,0 & 47,0 \\
\hline Standard deviation & 30,8 & 2685,2 & 9,0 \\
\hline Sampling variance & 949,6 & 7210511,2 & 81,3 \\
\hline Excess & 1,6 & 4,0 & 3,8 \\
\hline Asymmetry & $-0,7$ & 1,4 & $-1,8$ \\
\hline Interval & 170,9 & 16768,1 & 43,4 \\
\hline Minimum & 25,2 & 1854,8 & 13,7 \\
\hline Maximum & 196,1 & 18622,9 & 57,1 \\
\hline Reliability level $(95,0 \%)$ & 6,8 & 590,0 & 2,0 \\
\hline Variation, in \% & $\mathbf{2 6 \%}$ & $\mathbf{3 8 \%}$ & $\mathbf{2 0 \%}$ \\
\hline
\end{tabular}

The variation of the studied set is large for all indicators: this means that the number of non-cash purchases per year for 1 card varies greatly depending on the region $\pm 26 \%( \pm 30$ purchases per year) from the average for Russia, while the turnover on the card per month fluctuates more $\pm 38 \%$ ( \pm 2685 rubles per card per year) of the average for Russia. The share of payments by cards from the total turnover on cards can vary within the range of $\pm 20 \%$ (from $24 \%$ to $64 \%$, depending on entities). The range of variation (the ratio between the minimum and maximum values) is more than $200 \%$ for all indicators. Regions differ significantly from each other in all indicators of the development of non-cash payments. For example, Figure 2 shows the distribution of regions by the number of card payments. The largest number of regions is concentrated in the range from 120 to 139 purchases per year. However, there are $16 \%$ of regions where the number of card transactions per year is performed by a large margin from the average statistical level in Russia, as well as from «successful» regions. 


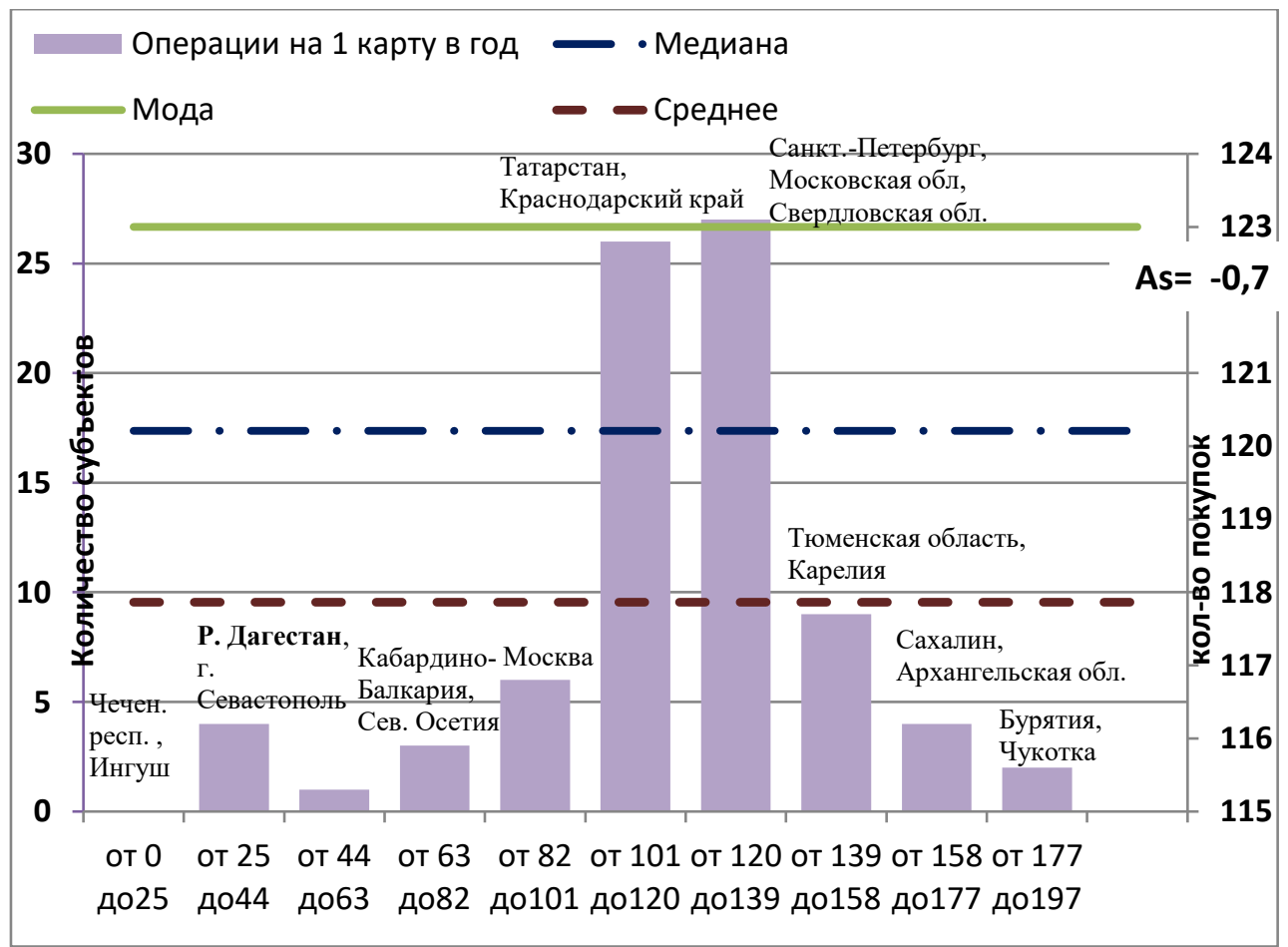

Fig. 2. The number of purchase transactions for 1 card in trade and service networks (TSN) in 2019, frequency distribution

Where: Количество субъектов - Number of entities; Операции на 1 карту в год - Transactions on 1 card per year; Медиана - Median; Мода - Mode; Среднеe - Average; Кол-во покупок - Number of purchases; Чеченская респ. - The Chechen Republic; Р. Дагестан, г. Севастополь - R. Dagestan, Sevastopol; Кабардино-Балкария, Сев. Осетия - Kabardino-Balkaria, North Ossetia; Москва Moscow; Татарстан, Краснодарский край - Tatarstan, The Krasnodar Territory; Санкт-Петербург, Московская обл. - St. Petersburg, The Moscow region; Тюменская обл., Карелия - The Туumen region, Karelia; Сахалин, Архангельская обл. - Sakhalin, The Arkhangelsk region; Бурятия, Чукотка - Buryatia, Chukotka; От - from, до - to.

\section{Results and discussion}

Let us focus on the regions lagging in the field of non-cash payments, for example, the Republic of Dagestan which is the largest in terms of population. In 2019, on the territory of the Republic of Dagestan, the number of electronic paying terminals for goods and services in 2019 increased by more than one and a half times. The population supply ratio with payment infrastructure is growing every year, and as at January 1, 2020, in two federal districts, there were 15,8 payment card receiving devices per 1000 residents. Growth compared to the same date last year is $19 \%$.

There are still about $27 \%$ of retail outlets that do not provide the opportunity to pay by credit card in Russia [5]. If they are obliged to install terminals, they will increase the share of expenses made by non-cash by $9 \%$. These are exactly those entrepreneurs and legal entities who, according to the law, have the right not to purchase terminals, since their revenue does not exceed 5 million rubles per year for entrepreneurs and 40 million rubles for legal entities. 
There are still retail outlets in Russia that do not provide the possibility of non-cash payments. According to Sberbank's estimates for the economy as a whole, more than a quarter of enterprises (27\%) have not installed terminals and still accept only cash for payment [7]. Installing terminals at such enterprises will increase the volume of payment by only $10 \%$. But since the average check here is too low, they may end up at a loss.

The number of electronic terminals used to pay for goods and services in the Southern Federal District and the North Caucasian Federal District in total exceeded 360 thousand devices, which is $23,5 \%$ more than the same indicator year ago. The most active POSterminal network developed in Dagestan, Crimea and Sevastopol - the growth rates are $55,6 \%, 55,5 \%$ and 50,2\% [8]. The Krasnodar Territory (131,6 thousand units), the Rostov Region (70,2 thousand units), the Stavropol Territory (41,2 thousand units), as well as the Volgograd Region (40, 7 thousand units) retained leadership in the number of POS terminals. These regions account for about $80 \%$ of all POS terminals in the SFD and the NCFD. However, POS terminals still have not gained popularity in Dagestan and only large points installed them [8].

Dagestan is one of the leaders in the North Caucasus Federal District in terms of the number of issued Mir cards: with a population of more than 3 million people, over 650 thousand cards of the national payment system have been issued in Dagestan [8]

\section{Conclusion}

As a result of our research, we identified several problems:

1. Poor equipment with POS-terminals of the lagging republics. However, it should be noted that the equipment with terminals does not depend on the willingness of retail chains to do this, but on the will of the population to pay with cards.

2. In the republics of the NCFD, as well as in the Republic of Dagestan, there are many individual entrepreneurs with insignificant revenues, and they quite legally have the right not to install terminals. But the problem is that most of them underestimate their revenue. This issue cannot be solved by administrative methods.

3. Low average consumer check. In the Republics of the North Caucasus, it is only 721 rubles. Installation of terminals will increase the volume of payments by only $10 \%$.

This should be started with consumers: they need to be interested in using a bank card, since the development of non-cash payments depends on consumer demand. If the average check is increased, and this is also a problem of consumer demand, income, then card turnover in the TSN will increase significantly.

\section{References}

1. A.V. Borisov, Cashless payments using plastic cards, Modern scientific research and innovations, 3 (2019) http://web.snauka.ru/

2. V.B. Zaitsev, E.V. Zaitseva, National payment system: current state, regulation and development prospects, 301 (2016)

3. D.A. Kurmanova, Management of Economic Systems, 6 (2015)

4. A.V. Yurov, Money and Credit, 3, 11 (2017)

5. Rating of "cashless" cities and regions. Results of 2019, https://www.sberbank.ru/

6. Money supply (national definition) maps, Central Bank of the Russian Federation, https://www.cbr.ru/ 
7. The number of payment cards issued on the territory of the region *, and operations with their use, made in Russia and abroad, by type of client, Central Bank of the Russian Federation, https://cbr.ru/

8. Results of the sociological research "The attitude of the population of the Russian Federation to cash" for 2018, https://cbr.ru/ 